\title{
Ventilation of operating-theatres.*
}

\author{
By ROBERT BLOWERS AND BERYL CREW \\ Public Health Laboratory, General Hospital, Middlesbrough
}

(Received 5 August 1960)

\section{INTRODUCTION}

For many years, surgical operation theatres have been provided with some form of ventilation equipment. This was usually designed with the sole object-by no means always achieved-of providing comfortable working conditions. In 1946 Bourdillon and Colebrook drew attention to another important function of ventilation in burns dressing-rooms and operation theatres. They showed that serious sepsis of burns and wounds could be caused by bacterial contamination from the air and that well-designed ventilation equipment could play a large part in preventing this.

Airborne bacteria in an operating-room can come from sources outside and inside the room. From the outside sources, air in hospital wards and corridors is often contaminated with pathogenic bacteria and may be sucked into the operatingroom by ventilation systems depending entirely on exhaust fans. Inside the room, contaminated particles may be shed from the coverings of septic wounds, from blankets, from the respiratory tracts, skin and clothing of the occupants of the room, and may be raised from the floor as the nurses move about their duties. Ventilation by an inadequate flow of air allows these organisms to accumulate and contaminate wounds during operations.

To reduce these risks, Bourdillon and Colebrook recommended ventilation of burns dressing-rooms by forcing a copious supply of filtered air into the room instead of sucking air out. This positive-pressure (plenum) system prevented contaminated air from flowing into the dressing-room from other parts of the hospital and quickly carried away organisms that were liberated inside the room. Counts of airborne bacteria during actual dressings were very much reduced and Lowbury (1954) showed that burns dressed under these conditions suffered less sepsis than those dressed in a room without plenum ventilation. Shooter, Taylor, Ellis \& Ross (1956) found that general surgical wounds were similarly protected by plenum ventilation of an operating room.

This method of ventilation has been widely adopted, but outbreaks of infection, apparently airborne, sometimes occur in theatres so equipped. During one such outbreak (Blowers, Mason, Wallace \& Walton, 1955), the plenum ventilation plant was removing bacteria at only a fraction of the speed of which it was capable. Simple modifications improved its performance enormously. This led to investigations in other theatres and to the discovery of great variations in the bacteriological

* This work is part of an investigation by the Public Health Laboratory Service for the Newcastle Regional Hospital Board and is financed by a grant from the Board. 
performance of plenum ventilation plants. These variations often seemed to depend on quite small differences of design, so the investigation reported here was made in an attempt to define the principles that should be observed in designing ventilation systems for operation theatres.

In this study we were mainly concerned with the bacteriological problems of ventilation, but we could not ignore the needs of comfort and have made some observations on them. The bacteriological studies fall naturally into two parts-the prevention of aerial contamination from outside the theatre and removal of organisms liberated inside it.

\section{MATERIALS AND METHODS}

\section{Operation theatres}

Field studies were made in twenty-two theatre suites in different parts of Britain, from Aberdeenshire to Hertfordshire. Ten of them had exhaust and twelve had plenum ventilation. In all of them we studied directions of air flow between different parts of the suite; and in most, made bacteriological studies of the air during actual operating sessions; whilst in a few, experimental studies were made after artificial contamination of the air. All the exhaust and seven of the plenumventilated theatres were built or designed before this investigation began and gave us the opportunity of recording conditions representative of those in most British operating-rooms. The remaining five theatres, more recently built, incorporated ventilation methods that had given promising results in the experimental theatre unit, described below, and in them we were able to study these methods in actual use.

Fundamental laboratory studies of ventilation could not be made in functioning operating-suites because it would have been impossible to make the many permutations of mechanical design that we wished to try. A full-sized dummy operating-room was therefore built. On a 'Dexion' angle-iron frame, hardboard panels were bolted to make a room $20 \mathrm{ft} . \times 20 \mathrm{ft} . \times 9 \mathrm{ft}$. $(6 \times 6 \times 2 \cdot 7 \mathrm{~m}$. $)$. Joints between the panels were sealed with 'Sellotape' so that, when the door was closed, the room was virtually airtight. The ventilation plant (Carrier Engineering Company) consisted of a centrifugal fan drawing air from outdoors and passing it through coarse and fine filters, and through heating and humidifying units under the control of adjustable thermostats. The maximum capacity of the plant was $160,000 \mathrm{cu}$. ft. (4500 cu. m.)/hr., giving just over forty changes per hour in the room. The flow of air was controlled by a damper in the main duct and indicated on an orifice-plate manometer. In the room, air was admitted through any or all of six rectangular apertures in the ceiling; to these, various types of air-distribution units could be fitted. The air-exhaust apertures, $12 \mathrm{in.}(30 \mathrm{~cm}$.) square, were almost at floor level in each of the four walls. The exact locations of these are described for the individual experiments.

\section{Bacteriological analysis of air}

The concentration of contaminated particles in the air was measured with a large slit-sampler (Bourdillon, Lidwell \& Thomas, 1948), and their rate of sedimentation 
on to surfaces by exposing $5 \frac{3}{4}$ in. culture plates. For both purposes the culture medium was nutrient agar. General bacterial counts were made after 18-24 hr. incubation but the plates were left for an additional $24 \mathrm{hr}$. at room temperature when Staphylococcus aureus counts were to be made. For isolation of Clostridium welchii, neomycin-Nagler medium (Lowbury \& Lilly, 1955) was used, and for Cl. tetani, nutrient gelatin (Lowbury \& Lilly, 1958).

\section{Artificial contamination of the air}

A broth suspension of the non-pathogenic aerobic spore-bearer Bacillus globigii (B. subtilis) was heated to destroy all vegetative forms. The resulting sporesuspension, standardized to a convenient density, was sprayed as a droplet-borne cloud into the room by a spinning-top atomizer (May, 1949) driven by compressed air. The mean diameter of the bacteria-carrying particles, controlled by varying the pressure of the air driving the atomizer, was adjusted to $15 \mu$, because this is about the size of contaminated particles in hospital air (Lidwell, 1959). In still air the bacterial cloud was concentrated around the atomizer so, when a wider distribution was required, an assistant walked quickly round the room during the spraying, beating the air with a three foot-square board on a long broom-handle. Preliminary sampling in different parts of the room showed that this gave almost uniform distribution of the bacterial cloud.

\section{Air velocities}

\section{Physical measurements}

Linear air velocities were measured by rotating-vane or deflecting-vane anemometers, and turbulent air velocities by a high-temperature kata-thermometer.

\section{Direction of air flow}

Flow through doorways was determined by watching the dense cloud of smoke from a cotton-wool swab dipped in titanium tetrachloride.

\section{Air-pressure differences}

Pressures across doorways were recorded on a Metrovick deflecting-vane anemometer.

\section{EXPERIMENTAL}

Prevention of airborne infection from sources outside the operating-room

\section{From outdoor air}

The bacterial content of outdoor air varies a great deal, depending on the neighbourhood, weather, and the height above ground. Most of the organisms are not pathogenic for surgical wounds, but $\mathrm{Cl}$. welchii and $\mathrm{Cl}$. tetani are present in measurable numbers whilst Staph. aureus is very occasionally found. The outdoor air-intake for the experimental operating-room was much closer to the ground than is usual so bacterial counts of the air around it were correspondingly higher. In this section we record the performance of a relatively simple filtration unit in removing these organisms. 
The air, on its way to the room, passed through a coarse glass-wool primary filter to remove gross dirt and insects, then through four Vokes $\mathrm{K} 600 \mathrm{Kompak}$ fabric filters in parallel. These have a rated efficiency of $99.9 \%$ for $5 \mu$ particles and are regarded by the makers as being relatively coarse filters. Table 1 shows the results of bacterial counts on the outdoor air around the intake and on air just inside the supply ducts before emerging into the room. For comparison, typical counts from the air taken during some fifty surgical operations are also shown. Filtration reduced the general count to such a low level that pathogens were no longer detectable. These counts are so much lower than those in functioning theatres that air filtered in this way seems acceptable for ventilation during surgical

Table 1. Bacterial counts of outdoor air before and immediately after filtration through Vokes K 600 Kompak filter. For each bacteriological group 43 samples of $35 \mathrm{cu}$. ft. $(990 \mathrm{l}$.) of filtered and unfiltered air were examined. Also shown are typical counts from room-air during operations; for ease of comparison, Staph. aureus counts during operations have been related to the same volume of air as the outdoor samples

\begin{tabular}{|c|c|c|c|c|c|c|}
\hline & \multicolumn{2}{|c|}{$\begin{array}{c}\begin{array}{c}\text { General bacterial } \\
\text { count: } \\
\text { colonies/cu. ft. }\end{array} \\
\end{array}$} & \multicolumn{2}{|c|}{$\overbrace{}^{\begin{array}{c}C l . \text { welchii } \\
\text { colonies/cu. } \mathrm{ft} .\end{array}}$} & \multirow[t]{2}{*}{$\begin{array}{c}\text { Staph. } \\
\text { aureus: } \\
\text { total } \\
\text { colonies } \\
\text { in all } \\
\text { samples } \\
\text { (1509 } \\
\text { cu. ft.) }\end{array}$} & \multirow[t]{2}{*}{$\begin{array}{c}\text { Cl. tetani } \\
\text { number } \\
\text { of } \\
\text { samples } \\
\text { yielding } \\
\text { Cl. tetani }\end{array}$} \\
\hline & Range & Mean & Range & Mean & & \\
\hline Unfiltered air & $3 \cdot 02-4 \cdot 00$ & $3 \cdot 26$ & $0-0.33$ & 0.09 & 4 & 29 \\
\hline Filtered air from duct & $0-0 \cdot 14$ & 0.07 & Nil & $\mathrm{Nil}$ & Nil & Nil \\
\hline $\begin{array}{l}\text { Air during operation } \\
\text { in exhaust-ventilated } \\
\text { room }\end{array}$ & $20-50$ & 30 & $0-0.23$ & $0 \cdot 05$ & 900 & Not done \\
\hline $\begin{array}{l}\text { Air during operation } \\
\text { in plenum-ventilated } \\
\text { room }\end{array}$ & $0 \cdot 5-5$ & 3 & $0-0.01$ & 0.006 & 45 & Not done \\
\hline
\end{tabular}

operations. We did not, therefore, investigate filters of higher efficiency, whose use creates greater impediment to the flow of air and thus calls for a larger, more expensive, and noisier power plant.

\section{From other parts of the hospital}

Airborne contamination of the operating-room from its immediate and remote environment can be prevented, as shown by Bourdillon and Colebrook, by increasing the air pressure in it so that air flows from the theatre to the environment instead of in the opposite direction. We have investigated the ability of different plenum ventilation arrangements to realize this reversal of flow.

In a functioning operating-room with a conventional plenum system the ventilation plant supplied $650 \mathrm{cu}$. $\mathrm{ft}$. of air $/ \mathrm{min}$. whilst extractor fans removed $450 \mathrm{cu}$. ft./ $\mathrm{min}$. The input surplus of $200 \mathrm{cu}$. $\mathrm{ft}$. $(5 \cdot 7 \mathrm{cu} . \mathrm{m}$.)/min. was, therefore, available to cause an outward flow to the environment. Using titanium tetrachloride smoke 
we observed the direction of air flow through the main doorway between the operating-room and the corridor.

When all doors were closed there was a strong outward flow through the gaps around them. When the large double doors were opened, a doorway of $30 \mathrm{sq}$. $\mathrm{ft}$. (2.8 sq. m.) was exposed. Through the top of this there was a gentle outward flow but as the smoke generator was lowered the flow lessened and, $4 \mathrm{ft}$. above the floor, ceased. At progressively lower levels an increasing inward flow was observed. When other doors, such as those to the sink-room and surgeons' scrub-room, were open as well, the outward flow was limited to a still smaller zone at the top of each doorway. The input surplus of $200 \mathrm{cu}$. $\mathrm{ft}$. $/ \mathrm{min}$. was not enough to ensure an outward flow across the whole area of even one open doorway. Even if the air had escaped uniformly through the whole doorway area, the outward movement would have been only $7 \mathrm{ft}$./min. In fact, all the small surplus of inlet air escaped through the top of the doorway, leaving none to pressurize the lower part of the room. Studies in six other plenum-ventilated theatres gave similar results.

The minimum input surplus needed to ensure an outward flow through the whole area of an open doorway was determined in the experimental theatre. For these experiments no air was extracted mechanically, so the whole air input could be regarded as the surplus available for pressurization. The effect of ventilation rates up to the maximum capacity of the plant $(2600 \mathrm{cu}$. ft./min.) was observed. We found that the rate needed to give an outward flow at all levels was directly related to the doorway area and was $33 \mathrm{cu} . \mathrm{ft}$./min. per sq. $\mathrm{ft}$. of doorway $(10 \mathrm{cu} . \mathrm{m} . /$ min./sq. m.). To ventilate a theatre so that it will be pressurized even with all doors open-and there are usually four or five-would thus call for an input surplus of 4000-5000 cu. ft./min., involving great expense and much noise. It has, however, been possible to manage operating-rooms so that during operations all doors are usually shut and no more than one is ever open at a time. We therefore suggest that the required input surplus be determined by the area of only the largest doorway. For a double door of the usual size, about $30 \mathrm{sq}$. $\mathrm{ft}$., this means about 1000 cu. ft. $(28$ cu. m.)/min.

But if this surplus is achieved by the usual practice of exhausting $75 \%$ of the input air, a gross input of over $5000 \mathrm{cu}$. ft./min.- about 75 room changes per hour -again becomes necessary. This is utterly impracticable and an apparent solution is to dispense entirely with exhaust ports so that all the input is available for pressurization when a door is open, as was done in the experimental theatre and in one functioning unit. When all the doors were closed the air had to find its own way out and this it did mainly through the gaps around the doors. But the outflow area thus available was so small that it limited the ventilation flow to $600 \mathrm{cu}$. ft./min. and impaired the performance of the plant in removing bacteria that were liberated inside the room. Moreover, work in the experimental theatre showed some advantages in having air exhaust ports in planned positions.

The ultimate solution was to place the exhaust ports in the desired positions and to equip them not with extractor fans, but with pressure-relief flap-valves. When all doors were closed the valves were opened by the air pressure and gave free escape for the air. When a door was opened, pressure in the room dropped, whereupon all 
the valves closed and made the whole air supply available to go out through the doorway. The valve (Fig. I) has an adjustable loading-weight, an external cowl to protect the flap from wind gusts, and fine gauze mesh to prevent ingress of birds. cats, and insects. When the valves are fitted to an inside wall the cowls are sometimes omitted.

This system has been applied in five operating-suites and has proved satisfactory. It has, however, been necessary to make allowance for the fall of input that occurs as air filters become blocked, so plants have been designed to deliver, through new filters, rather more than the required minimum flow. In smoky industrial areas an

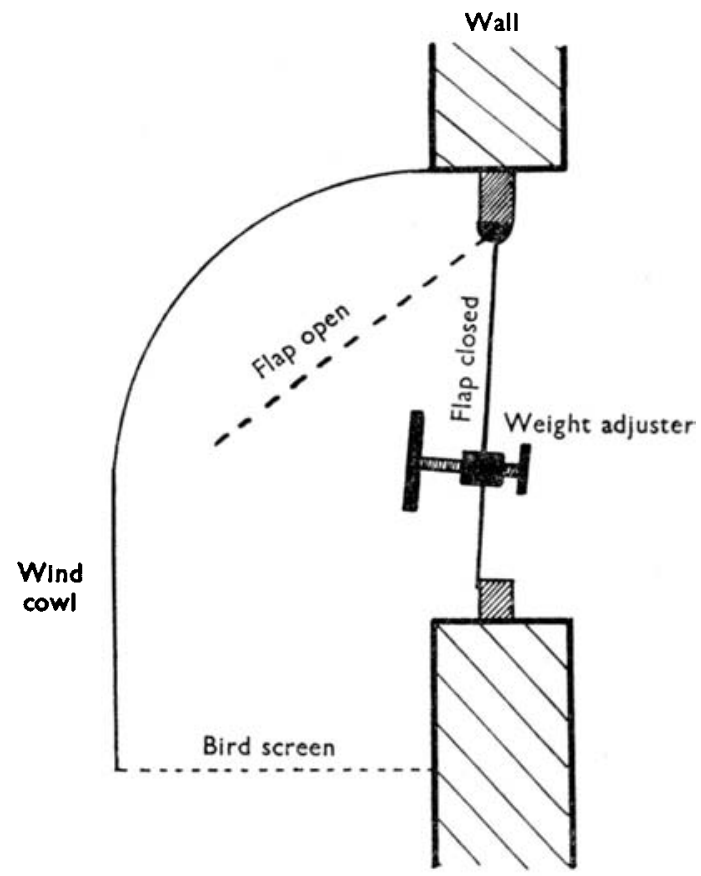

Fig. 1. Pressure-relief flap-valve fitted to exhaust port in wall. Air pressure in the room is increased by screwing the weight outwards.

initial input surplus of $40 \mathrm{cu}$. ft./min. for each square foot of the largest doorway (12 cu. m./sq. m.) has ensured full pressurization for several weeks before the filters have to be changed.

All rooms of the operating-suite in which sterile equipment is exposed have been ventilated in this way and satisfactory ventilation rates have been $1200 \mathrm{cu} . \mathrm{ft}$. (34 cu. $\mathrm{m}$.)/min. for operating and anaesthetic rooms (which have large double doors), and $850 \mathrm{cu}$. ft. (24 cu. m.)/min. each for scrub, sterilizing, and sink (sluice) rooms. In some of the units we have studied, plenum ventilation has not been provided for the sink-room because sterile equipment is not exposed in it. Though this economy may be justified on bacteriological grounds it has proved less so on grounds of comfort.

A possible result of pressurizing the ancillary rooms in this way is that air may flow from them into the operating-room. This is undesirable because the anaesthetic, 
scrub, and sink-rooms are liable to aerial contamination during, respectively, the movement of bedding, the scrubbing of hands, and the disposal of contaminated dressings. We therefore prevented air flow into the operating-room by adjusting the weights of the pressure-relief valves so that those in the operating-room were more heavily loaded than those in the ancillary rooms. Smoke tests then showed that when an intervening door was opened, the air chose an exit via the more lightly loaded valves and always flowed from the operating-room to the ancillary room.

For the sterilizing-room there are different requirements. Airflow into it from the operating-room is unacceptable because sterile equipment for a later operation may be exposed in it while the operating-room is heavily contaminated, as during an operation on a grossly septic burn; but a flow in the other direction, though acceptable bacteriologically, is unsatisfactory because it causes overheating of the operating-room. The best arrangement, therefore, is to set the exhaust-flap loadings so that there is no flow in either direction. In practice we have rarely been able to realize this when, as is usual, the two rooms are at different temperatures. The best setting has then been one that gives a slight drift, shown by smoke tests, in one direction at the top of the doorway and in the other direction at the bottom. These drifts could be prevented only by fitting a door in the opening and keeping it closed during operations.

This account of the relative pressures and directions of flow between the different rooms of the suite may be confusing so is summarized thus:

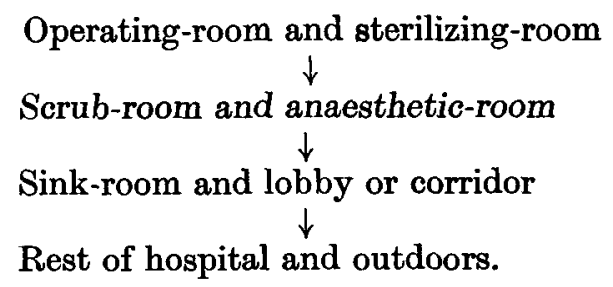

Provided there is a strong flow in these directions through the gaps round closed doors and through open doorways, the actual pressure differences are immaterial. Usually, however, a static pressure difference of $0 \cdot 1 \mathrm{in} .(0 \cdot 25 \mathrm{~cm}$.) of water across the bottom of a closed door is sufficient.

\section{From adjoining operating-rooms}

The preceding account shows how we have been able to prevent ingress of contaminated air to the theatre suite from the rest of the hospital, and to control the flow of air between the rooms of the suite. The system has worked well in selfcontained suites consisting of one operating-room served by its own ancillary rooms. When it has been applied to 'twin' theatre units with two operating-rooms served by common ancillaries, some difficulties have arisen.

A plan of one such unit is shown in Fig. 2. When all the doors were closed or when any one door was open, the arranged pressure differences caused air to flow in the desired directions as indicated by the arrows (Fig. 2 A). But when the doors at both ends of an ancillary room were open at the same time as that between Theatre 1 
and the corridor, the loss of pressure in Theatre 1 made it an exhaust-path for air from Theatre 2 (Fig. $2 \mathrm{~B}$ ). This could be reduced to an insignificant leak by closing either or both of the ancillary-room doors. In some units, however, such doors were not provided and a cross-flow could be demonstrated whenever a main operating-room door was opened.

To measure the bacteriological consequences of this cross-flow, we liberated an airborne cloud of Bacillus globigii in Theatre 2 while all doors were closed. Five minutes later both sterilizing-room doors and the door between Theatre 1 and the
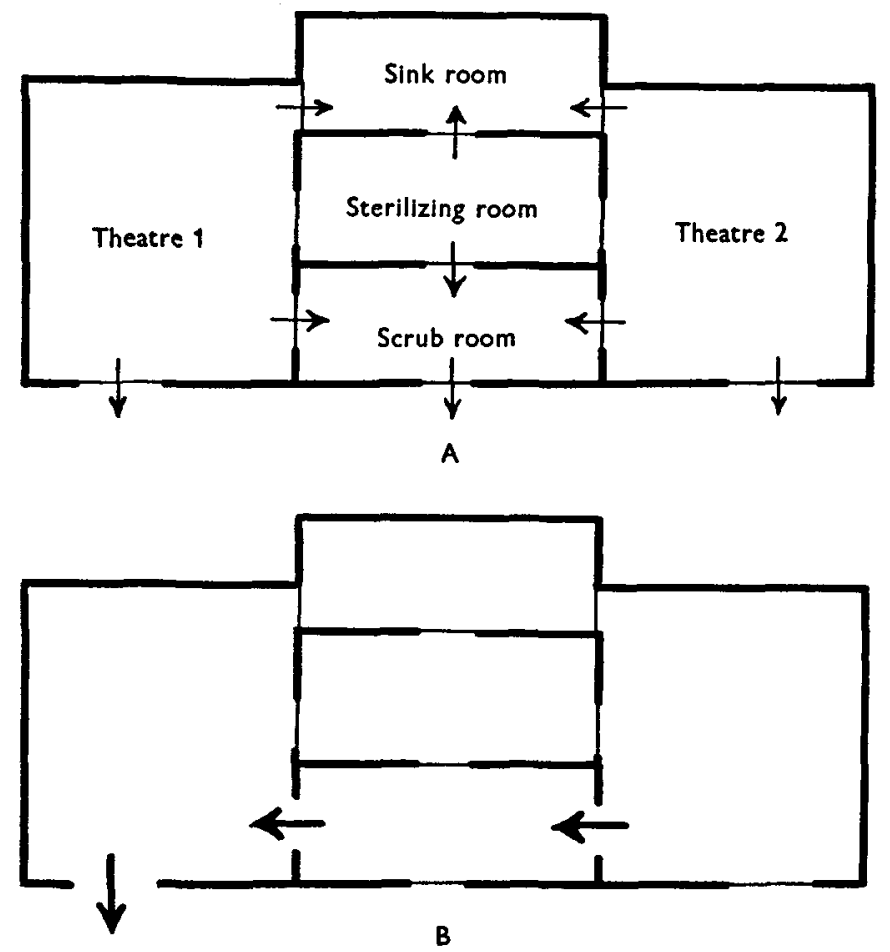

Fig. 2. Cross-contamination between operating-rooms in 'twin' unit. A. Shows all doors closed with slight air flow through gaps from high-pressure 'clean' areas to lowpressure 'dirty' areas. Opening of any one door does not seriously upset this fow. B. Shows strong cross-flow between operating-rooms if intervening doors and one door to corridor are open.

corridor were opened while the concentrations of airborne bacteria in both theatres were measured by continuous slit-sampling. The concentration in Theatre 2 was 44 contaminated particles/cu. ft. and within two minutes of the doors being opened was $10 / \mathrm{cu}$. ft. in Theatre 1.

We have not had an opportunity of investigating cross-contamination such as this during actual operations because the circumstances under which it occurs arise at unpredictable times. But heavy aerial contamination is known to occur during some procedures on septic tissues so a cross-flow of air may occasionally expose a clean wound in the adjoining theatre to a risk of infection. The conclusion is that ancillary rooms should be separated from operating-rooms by doors, which should be kept closed during operations. 


\section{Prevention of contamination from sources inside the operating-room}

The possible sources of aerial contamination inside an operating-room have been mentioned in the Introduction. Detailed studies of ventilation methods for removing the organisms are not easily made during actual surgical operations because dissemination is irregular and unpredictable. Studies of the clearance of organisms shed from one source are obscured by those shed from another before the observation is completed. Comparisons between different ventilation methods in different operating-rooms are difficult because the amount of dissemination depends on activity of staff and other variable factors which differ widely from one hospital to another. Our basic studies of this problem were, therefore, made in the experimental operating-room after artificial contamination of the air.

There is no single test that will measure all the required functions of ventilation in removing airborne bacteria; indeed, we do not know precisely what functions are required of it though two elementary needs seem obvious. The first is that after widespread contamination, such as occurs during the activity at the beginning and end of operations, the organisms should be removed as quickly as possible; the other is that bacteria shed from a localized source during an operation, as from a Staph. aureus carrier or from the floor, should be carried away without being brought into the critical area near the wound and the sterilized equipment. Our tests were devised to measure these functions of ventilation.

\section{Removal of bacteria after widespread contamination.}

The room was contaminated by running the atomizer near the centre while an assistant operated the 'beater' to distribute the organisms. Beating continued for one minute after spraying then a quiet interval of one minute was allowed for turbulence to die down. This routine gave a uniform contamination of 400-500 particles/cu. ft. - a much heavier contamination than is found in practice but more convenient for observations on rate of disappearance. The ventilation plant, and the slit-sampler in the centre or other part of the room under investigation, were then turned on simultaneously. Air sampling was continued until the counts were expected, from previous experience, to have fallen far enough for reliable calculations to be made. Five minutes was usually long enough. During the sampling period a sedimentation plate to represent the wound was exposed beside the sampler. Relevant air temperatures, relative humidity, and air velocities were noted at the beginning and end and sometimes during each run. Finally, ventilation was continued to clear the room in readiness for the next run. For each set of ventilation conditions at least twenty runs were made. After incubation of the plates, the colonies of Bacillus globigii were counted and each colony was taken to represent one contaminated particle from the air.

The performance of each ventilation system was determined by calculating the Equivalent Ventilation Rate which indicates the rate at which bacteria are removed, and the Sedimentation Index which indicates the degree of contamination a wound receives while the organisms are being removed.

The Equivalent Ventilation Rate $\left(K_{R}\right)$ compares the performance of each venti- 
lation system with the performance of what may be regarded as a standard system in which uniform turbulence causes rapid and complete mixing of incoming clean air with contaminated air already in the room. It indicates how many air changes per hour would be needed for the standard system to achieve a similar performance; and gives to ventilation performance a numerical value directly proportional to the speed with which contaminated particles are removed. A higher value thus indicates a better performance. The Equivalent Ventilation Rate was determined by plotting the logarithms of the slit-sampler counts against time and drawing the best-fitting straight line through them. From any two points on this line the disappearance rate of organisms from all causes, including death, sedimentation, and ventilation was calculated by applying the formula:

$$
K \text { (disappearance rate })=\frac{\left(\log n_{1}-\log n_{2}\right) 138}{t} \text { equivalent air changes } / \mathrm{hr} \text {., }
$$

where $n_{1}$ and $n_{2}$ are the numbers of bacteria present at any two moments and $t$ is the time in minutes between these moments. (For derivation of this formula see Bourdillon, Lidwell \& Lovelock, 1948). By separate experiment the disappearance rate without ventilation $\left(K^{\prime}\right)$ was determined in the same way. The disappearance rate due to ventilation or Equivalent Ventilation Rate $\left(K_{R}\right)$ was then obtained from the formula:

$$
K_{R}=K-K^{\prime} \text {. }
$$

The Sedimentation Index is an expression of the number of bacteria settling on the plate or thrown on to it by air currents during ventilation. A lower value thus indicates a better performance. Unlike the Equivalent Ventilation Rate which depends on the slope of a graph and is independent of the initial concentration of organisms, the number of bacteria settling on a plate is affected by their initial concentration so the Sedimentation Index must take account of it and is determined thus:

$$
\text { Sedimentation Index (s.I.) }=\frac{\text { Particles settling } / \text { sq. ft. } / \text { min. }}{\text { Particles/cu. ft. at start of run }} \text {. }
$$

Using these methods we have studied the effects of: type, number, and position of air inlet orifices, number and position of exhaust ports, temperature, humidity, the amount of ventilating air, human activity, the presence of an operating-room lamp over the sampling area, and opening of doors.

Air-inlet arrangements. Air was supplied to the room at a rate corresponding to 17 changes/hr.; temperature, humidity, and exhaust arrangements remained constant. The main methods examined are shown diagrammatically in Fig. 3 together with the results obtained from them. Comments on each are given here:

Arrangement 1: air was blown across the room to cause violent turbulence in the sampling area. The Equivalent Ventilation Rate was much lower than the actual rate (17 changes $/ \mathrm{hr}$.); contamination of the exposed plate was heavy, giving a Sedimentation Index of 8.15.

Arrangement 2: air blown vertically downwards into the room through six rectangular holes in the ceiling caused considerable but lesser turbulence and gave more rapid removal and less contamination. 
Arrangement 3: this was essentially similar to the common practice of siting air-inlet louvres along the top of one wall. The Equivalent Ventilation Rate was very close to the actual rate, suggesting that this arrangement gave almost uniform turbulence.

Arrangement 4: air projected horizontally through six inverted T-ducts in the ceiling caused still less turbulence with still more rapid removal and less contamination.
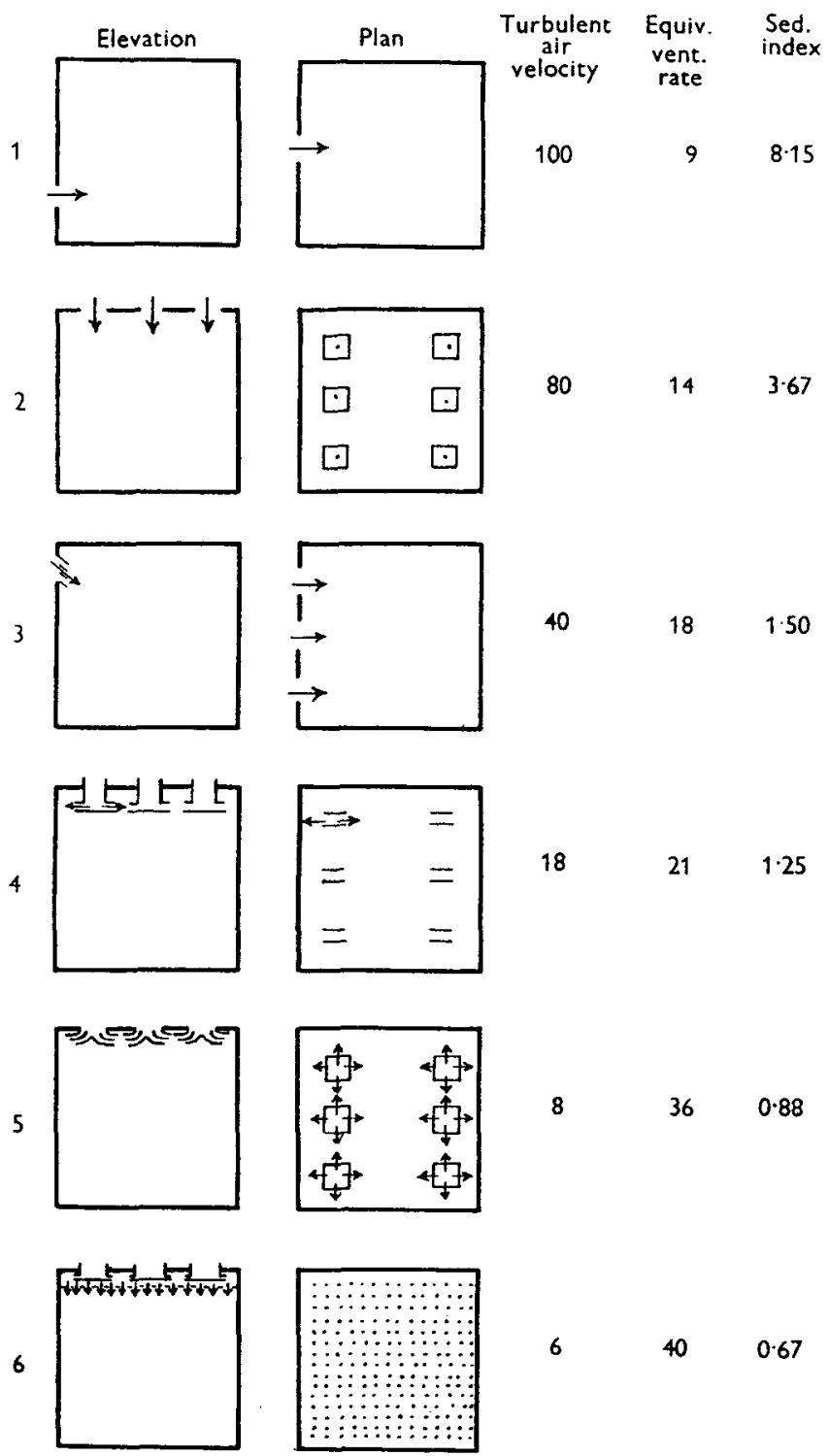

Fig. 3. Performance of various air-inlet arrangements. After uniform contamination of the room, ventilation at 17 changes/hr. was used with the indicated inlets. Airexhaust arrangement E (see Fig. 5) was used throughout and the temperature-difference was $3-5^{\circ} \mathrm{F}$. 
Arrangement 5: six modified commercial ceiling diffusers (Fairitt 'Airmaster', Fig. 4) gave horizontal projection of the air through $360^{\circ}$ with very rapid removal and little contamination $\left(K_{R}=36\right.$; s.I. $\left.=0 \cdot 88\right)$. With only four such diffusers, in the corner positions, $K_{R}$ fell to 18 , but in a smaller (e.g. sterilizing) room $10 \mathrm{ft}$. square, a single diffuser was sufficient for the best results. The unmodified diffusers giving a downward slant to the airstream, gave more turbulence and less satisfactory results.

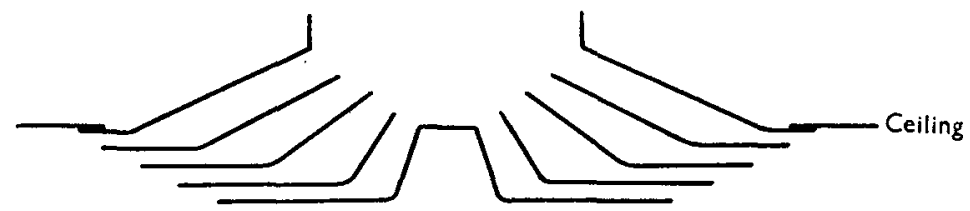

Fig. 4. Modified air diffuser. Horizontal extensions have been fitted to the inclined blades so that air is discharged horizontally instead of obliquely downwards.

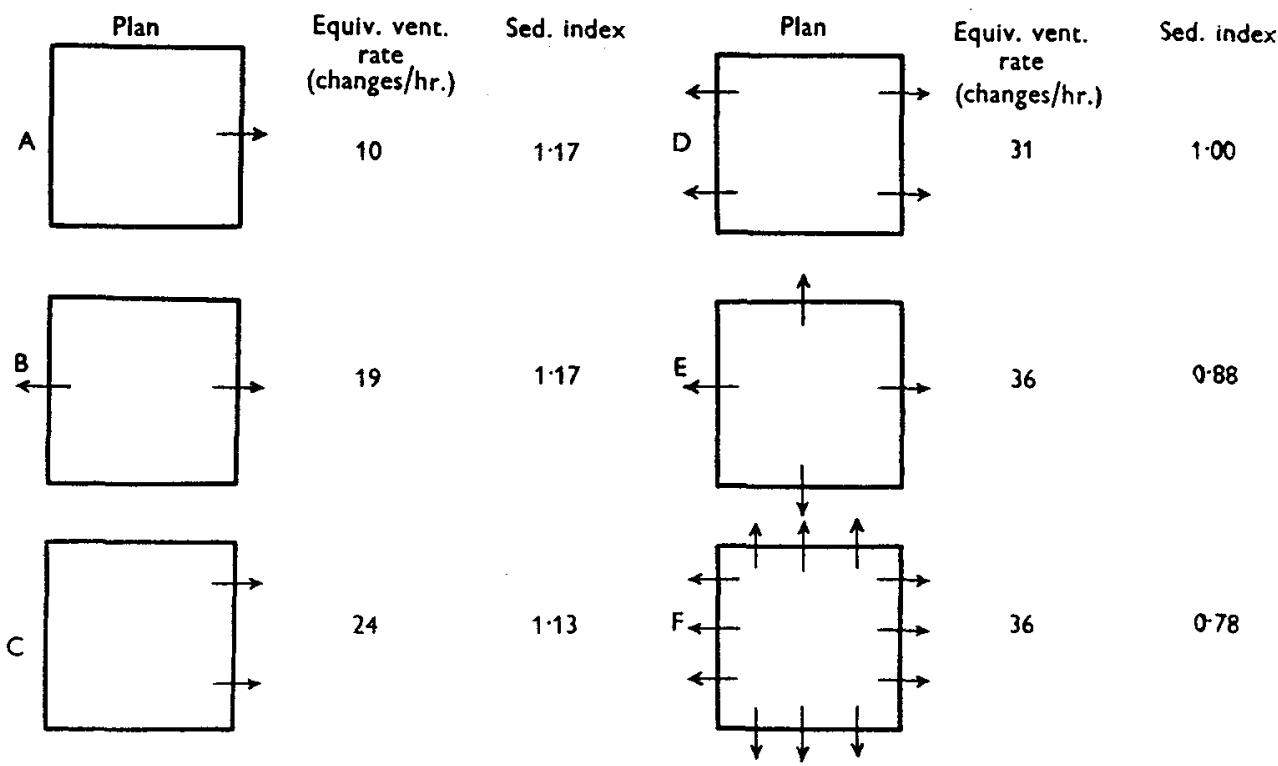

Fig. 5. Performance of various air-exhaust arrangements. After uniform contamination of the room, ventilation at 17 changes $/ \mathrm{hr}$. was used with the indicated exhaust ports, each $1 \mathrm{ft}$. sq. and with the bottom edge almost at floor level. Inlet arrangement no. 5 (see Fig. 3 ) was used throughout and the temperature-difference was $3-5^{\circ} \mathrm{F}$.

Arrangement 6: a uniformly perforated ceiling inlet was improvised, at the suggestion of Dr O. M. Lidwell, by fixing a sheet of hessian cloth as a false ceiling just below the baffled inlets. This gave results slightly better than Arrangement 5 .

Air exhaust arrangements. Fig. 5 shows that with inlet arrangement no. 5 almost the best results were obtained with one low-level exhaust port in each wall; more ports than this gave only slightly better results. From experiments, not illustrated in the figure, we found that results with the more turbulent inlet arrangements (1, 2 and 3) were relatively uninfluenced by the outlet arrangement. 
Temperature. With the best air-distribution arrangements as determined by the two previous experiments, room temperatures ranging from $50-90^{\circ} \mathrm{F}$. $\left(10-32^{\circ} \mathrm{C}\right.$.) did not significantly affect the Equivalent Ventilation Rate and Sedimentation Index. Results were, however, greatly influenced by the temperature-difference between the air leaving the inlet diffusers and that in the sampling area. Fig. 6 shows the effect of varying this. It is clear that warm air ventilating a cool room causes less turbulence and more rapid clearance of bacteria than does cool air ventilating a warm room. It is also associated with a correspondingly lower Sedimentation Index though this is not shown in Fig. 6.

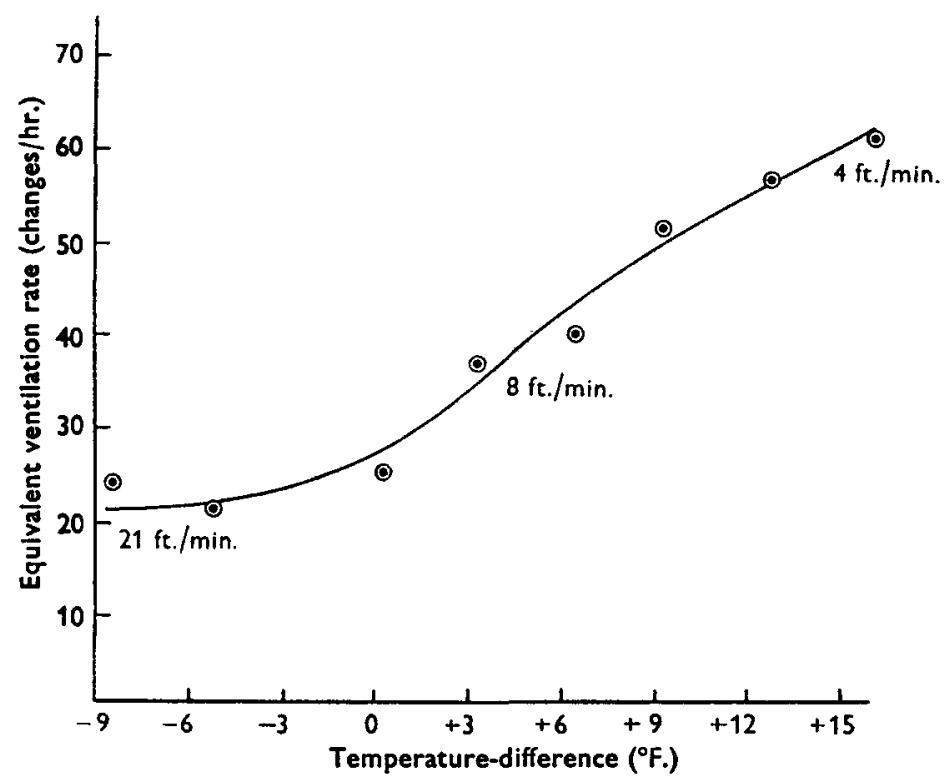

Fig. 6. Effect on Equivalent Ventilation Rate of temperature-difference between air leaving inlets and air in sampling area near operating table. Positive difference values indicate that the inlet air was warmer. Turbulent air velocities (in feet per minute) at the sampling area are shown against the graph. Inlet/outlet arrangements $5 / E$ (see Figs. 3 and 5) were used throughout and the ventilation rate was 17 changes $/ \mathrm{hr}$.

Humidity. Relative humidities ranging from 32 to $80 \%$ had no observable effect on Equivalent Ventilation Rate or Sedimentation Index.

Ventilation rate. Fig. 7 shows the effect of progressively increasing the ventilation rate from 300 to $2200 \mathrm{cu}$. ft./min. for two low-turbulence air-inlet systems. With the modified diffusers giving a horizontal spread of air (Arrangement 5) the results improved more or less proportionately to the amount of air supplied until this reached $1200 \mathrm{cu} . \mathrm{ft} . / \mathrm{min}$. (20 changes $/ \mathrm{hr}$.) with air leaving the diffusers at $350 \mathrm{ft}$. $/$ min. and a turbulent velocity in the centre of the room of $14 \mathrm{ft} . / \mathrm{min}$. Beyond this there was little further improvement due, we think, to the turbulence that occurred as the opposing air streams from adjacent diffusers met. This is supported by the fact that with the perforated ceiling (Arrangement 6), from which there are no opposing streams, turbulence remained low and results continued to improve up to the maximum capacity of the plant. Until the critical turbulence 
level of $14 \mathrm{ft} . / \mathrm{min}$. was passed, however, there was little difference between the performances of the two systems.

Activity. The effect of two people walking continuously and briskly round the room was observed during ventilation by the uniformly turbulent system (Arrangement 3) and a less turbulent system (Arrangement 5). For the turbulent system, the results were essentially unaltered; for the less turbulent system, the activity caused a deterioration of results so that they were almost the same as for the turbulent system-Equivalent Ventilation Rate 24 and Sedimentation Index 1·30.

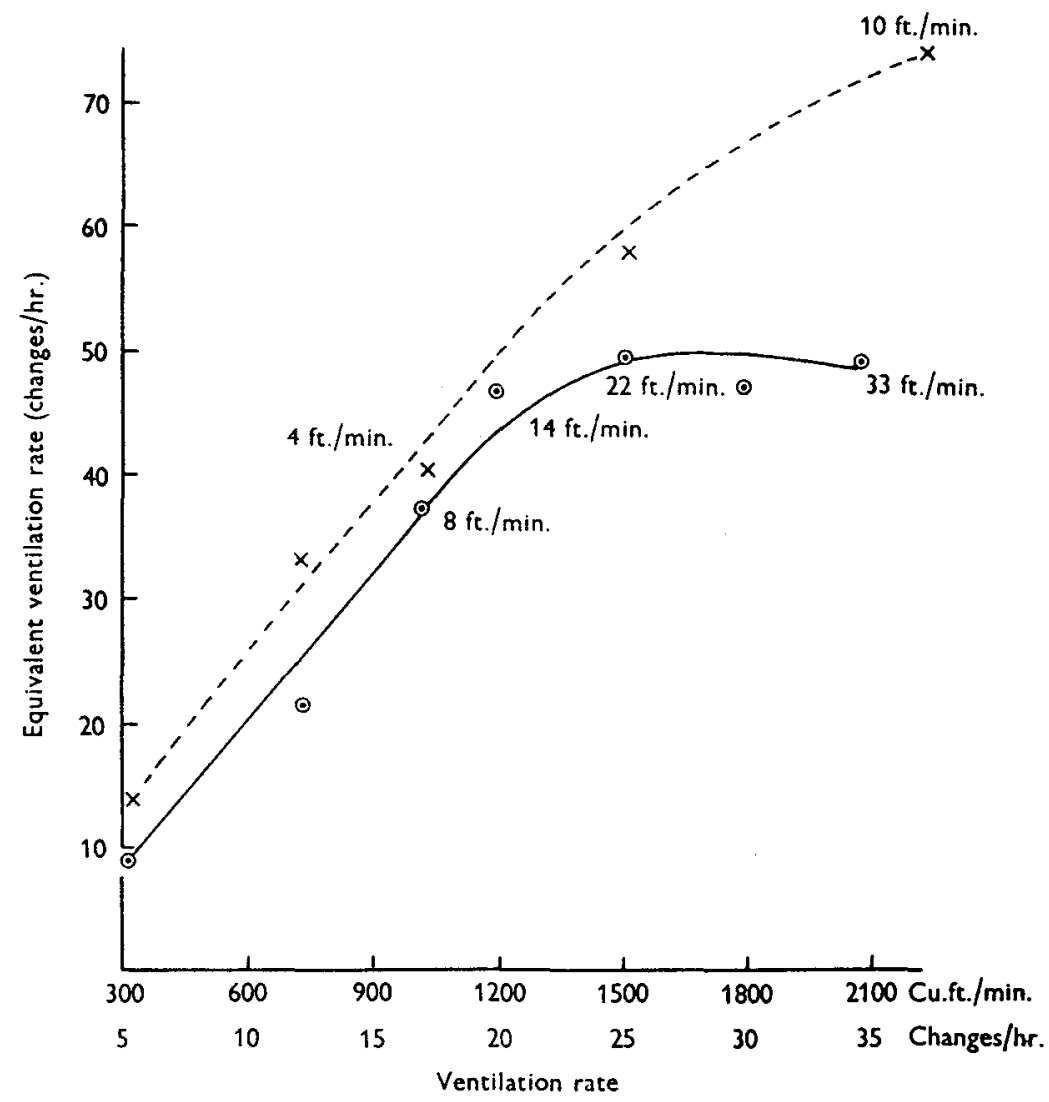

Fig. 7. Relationship between ventilation rate and Equivalent Ventilation Rate for two low-turbulence systems with a temperature-difference of $3-5^{\circ} \mathrm{F}$. Turbulent air velocities in feet per minute at centre of room are shown against the curves. $-\odot$ - arrangement $5 / E$ (see Figs. 3 and 5 ); $\ldots . . .$. arrangement $6 / E$ (8ee Figs. 3 and 5).

Presence of operating-lamp. The lamp, $3 \mathrm{ft}$. in diameter and fully illuminated, was suspended $3 \mathrm{ft}$. above the sampling equipment. It had no effect on the results of the turbulent ventilation system. With the less turbulent system the Equivalent Ventilation Rate was reduced from 36 to 29 but contamination of the exposed plate was slightly reduced, giving a Sedimentation Index of $0 \cdot 8$.

Open doorways. In a completed operating-room, Equivalent Ventilation Rate and Sedimentation Index were determined with all doors closed and with various doors 
open (Table 2). One or more doorways open to lower pressure-zones (scrub and sink-rooms) caused a marked loss of ventilation efficiency. Smoke tests showed this to be due to a loss of clean air through the tops of the doorways before it could descend to the sampling equipment on the operating-table. A doorway open to an equal pressure-zone (sterilizing-room) caused a smaller and rather inconsistent change.

From these experiments it appears that rapid removal of bacteria and low contamination of exposed surfaces are associated with ventilation systems that cause the least possible turbulence. The essential difference between the turbulent and nonturbulent ventilation systems is shown in Pls. 1 and 2 (p. 448) from photographs taken while smoke was being fed into the main ventilation duct. The turbulent system caused rapid mixing of clean and dirty air so the bacteria were removed by dilution; the non-turbulent system caused the clean air to descend in a piston-like manner and to displace the dirty air bodily before it.

Table 2. Effect of open doors on ventilation performance in a newly-built operatingroom with downward-displacement ventilation at 15 changes/hr. and a positive temperature-difference, during these experiments, of $5^{\circ} \mathrm{F}$.

$\begin{array}{lcc}\text { Doors open } & \begin{array}{c}\text { Equivalent } \\ \text { ventilation } \\ \text { rate }\end{array} & \begin{array}{c}\text { Sedimentation } \\ \text { index }\end{array} \\ \text { None } & 24 & \mathbf{1 \cdot 3 5} \\ \text { Sterilizing-room } & 25 & 1 \cdot 87 \\ \text { Scrub-room } & 14 & \mathbf{2 \cdot 3 7} \\ \text { Scrub, sink and sterilizing-rooms } & 7 & \mathbf{3 \cdot 0 0}\end{array}$

Though displacement is better than turbulent ventilation for clearing heavy contamination from an operating-room, after localized dissemination the results are less clear-cut.

\section{Removal of bacteria after localized dissemination}

The slit-sampler and an exposed Petri-dish were set in the position of the operating-table at the centre of the room. The atomizer was put in four different contamination sites to represent different sources of bacteria during operations; these were:

Site 1. $2 \mathrm{ft}$. from sampling point, $5 \mathrm{ft}$. above floor.

Site 2. $2 \mathrm{ft}$. from sampling point, $1 \mathrm{ft}$. above floor.

Site $3.8 \mathrm{ft}$. from sampling point, $5 \mathrm{ft}$. above floor.

Site 4. $8 \mathrm{ft}$. from sampling point, $1 \mathrm{ft}$. above floor.

Sites 1 and 2 represented the surgeon and his assistants and sites 3 and 4 the nurses. Atomization from the high-level sites represented scatter of bacteria from the nose and upper parts of the clothing, and from low-level sites it represented scatter from the lower clothing and disturbance of particles from the floor.

For each experiment a slit-sampler run was first made to confirm the absence of B. globigii remaining from the previous experiment. Then, with the ventilation plant running, $5 \mathrm{~min}$. continuous sampling was made on to a single slit-sampler 
plate and a single sedimentation plate. During the first minute of the sampling period, bacteria were liberated at a steady rate from the contamination site without any attempt to distribute them throughout the room.

From the slit-sampler plate we calculated the Exposure to Bacterial Contamination, an indication of the proportion of liberated organisms that reached the sampling area, and from the sedimentation plate we calculated the Actual Bacterial Contamination. Our reason for making this second measurement was the doubt whether the concentration of bacteria in the air, as indicated by the slit-sampler, is necessarily a valid indication of the number that are impacted on a wound by moving currents of air. The two indices were calculated thus:

Exposure to Bacterial Contamination = (No. of colonies/cu. ft. during whole slit-sampling period) $\times($ duration of sampling period in minutes)

\section{Millions of organisms liberated}

Actual Bacterial Contamination $=$

(No. of colonies settling per sq. ft. during whole sedimentation period) $\times($ duration of sampling period in minutes)

\section{Millions of organisms liberated}

These two indices are not numerically comparable with each other nor with similar indices based on different units such as volumes and concentrations of a gas (Williams $\&$ Lidwell, 1960). Thus, a value for Exposure to Bacterial Contamination can be compared only with another such value. Each was determined for a turbulent and for a displacement ventilation system with liberation from the various contamination sites. The mean values from seven observations for each site and for each ventilation system are shown in Table 3. For turbulent air velocities up to $40 \mathrm{ft}$. $/ \mathrm{min}$.

Table 3. Performance of turbulent and downward-displacement ventilation during localized contamination of room from the various sites described in text. The ventilation rate was 17 changes/hr. with a positive temperature-difference of $3-5^{\circ} \mathrm{F}$. Each value is the mean from seven observations; those in parentheses are from widely varying results and are only approximate

\begin{tabular}{|c|c|c|c|c|c|c|c|c|}
\hline \multirow{2}{*}{$\begin{array}{c}\text { Type of } \\
\text { ventilation; } \\
\text { air velocity in } \\
\text { centre of room } \\
\text { (ft./min.) }\end{array}$} & \multicolumn{4}{|c|}{$\begin{array}{l}\text { Exposure to bacterial } \\
\text { contamination : organisms per } \\
\text { cubic foot } \times \text { minutes per } \\
\text { million liberated }\end{array}$} & \multicolumn{4}{|c|}{$\begin{array}{l}\text { Actual bacterial } \\
\text { contamination: organisms per } \\
\text { square foot } \times \text { minutes per } \\
\text { million liberated }\end{array}$} \\
\hline & $\begin{array}{c}\text { Site } \\
\mathbf{1}\end{array}$ & $\begin{array}{c}\text { Site } \\
\mathbf{2}\end{array}$ & $\begin{array}{c}\text { Site } \\
\mathbf{3}\end{array}$ & $\begin{array}{c}\text { Site } \\
4\end{array}$ & $\begin{array}{c}\text { Site } \\
1\end{array}$ & $\begin{array}{c}\text { Site } \\
2\end{array}$ & $\begin{array}{c}\text { Site } \\
\mathbf{3}\end{array}$ & $\begin{array}{c}\text { Site } \\
\mathbf{4}\end{array}$ \\
\hline Turb & $(250)$ & - & - & - & $(950)$ & - & - & - \\
\hline & 378 & 244 & 180 & 126 & & 202 & 115 & 90 \\
\hline Displacement; 8 & 419 & 49 & 14 & Nil & 924 & 44 & 10 & $\mathrm{Nil}$ \\
\hline
\end{tabular}

both indices place the two ventilation systems in the same order of merit, suggesting that impingement of bacteria on the wound by air currents is not excessive. At $100 \mathrm{ft}$./min., however, a lower exposure to contamination is accompanied by a higher actual contamination presumably because the greater amount of air striking 
the wound brings a significantly larger number of bacteria in contact with it. Air velocities as high as this rarely occur in practical turbulent ventilation systems but the possibility of increased contamination from them should be borne in mind. Our references to turbulent systems from now on refer to those with air velocities of $40 \mathrm{ft} . / \mathrm{min}$.

With organisms liberated close to and above the operating table (Site 1) displacement ventilation allowed nearly twice as much contamination as did turbulence. But with liberation close to and below the table and from both levels
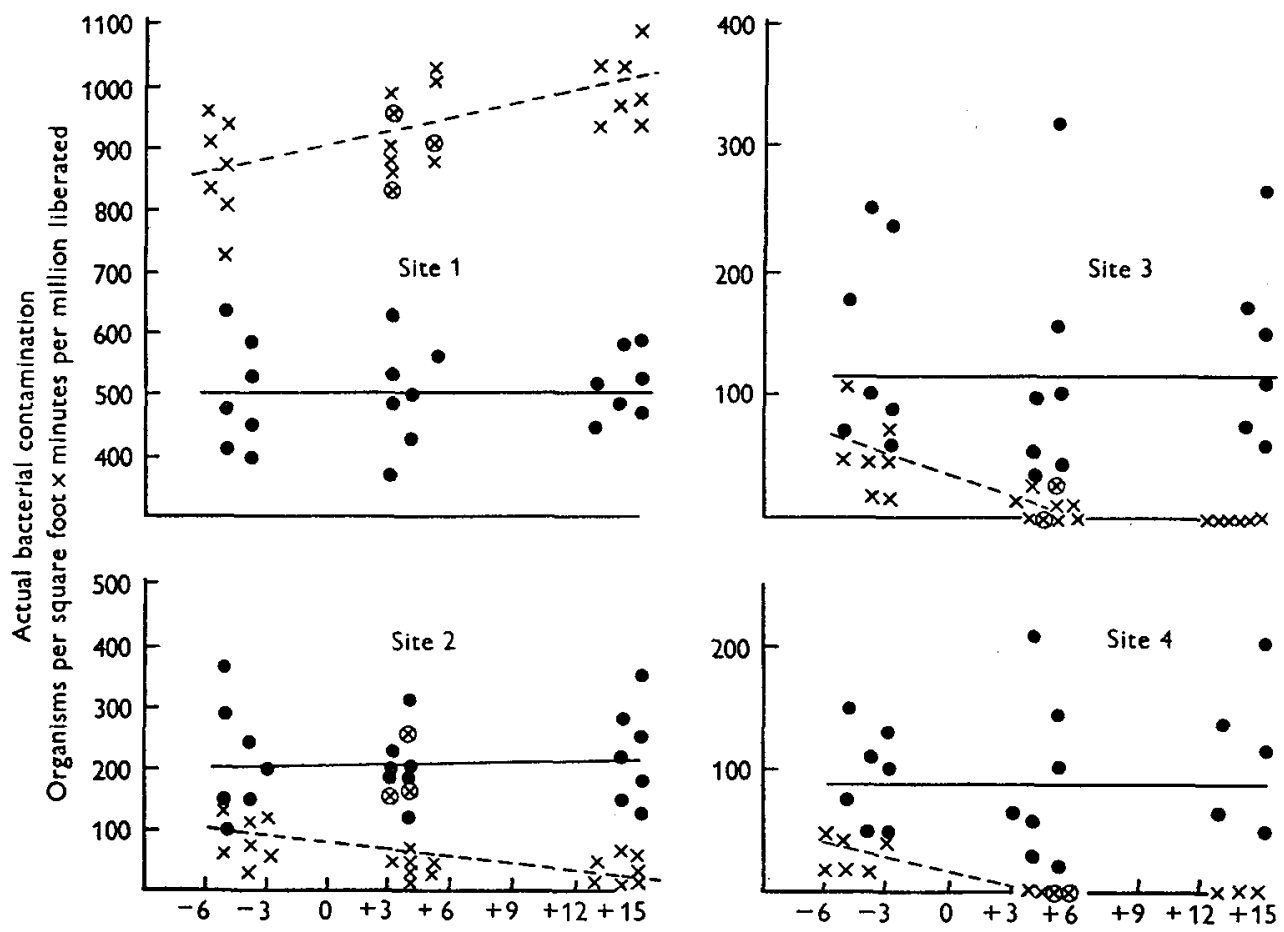

Fig. 8. Effect of temperature-difference on contamination in centre of room from four sites: Site 1: $2 \mathrm{ft}$. from table, $5 \mathrm{ft}$. above floor; Site $2: 2 \mathrm{ft}$. from table, $1 \mathrm{ft}$. above floor; Site 3: $8 \mathrm{ft}$. from table, $5 \mathrm{ft}$. above floor; Site $4: 8 \mathrm{ft}$. from table, $1 \mathrm{ft}$. above floor. For all experiments the ventilation rate was 17 changes $/ \mathrm{hr}$. The vertical scale for sites 3 and 4 is double that for sites 1 and 2. - - turbulent ventilation system $3 / C$ during quiet conditions (see Figs. 3 and 5); . . - . . - displacement ventilation system $5 / E$ during quiet conditions (see Figs. 3 and 5 ); $\otimes$ displacement ventilation during activity.

further away (sites 2, 3 and 4), contamination with displacement was at most a fifth of that of turbulence. From all sites and with both systems, contamination was less when the air-turnover was increased from 17 to 25 changes $/ \mathrm{hr}$.

The effect of varying the temperature-difference between incoming and room air is shown in Fig. 8. For the turbulent system, the effect was insignificant. For displacement, reduction of temperature-difference, which reduces the degree of displacement and increases turbulence, caused the level of contamination to approach that of the turbulent system: contamination from Site 1 decreased and from Sites 
2, 3 and 4 increased. Yet even with a difference of $-6^{\circ} \mathrm{F}$., as might occur during hot weather, the general differences of performance between the two systems remained.

Contamination levels during extreme activity--probably greater than during most operations-are marked by the encircled points in Fig. 6. For displacement ventilation with contamination below the table (Site 2), these points lie above the general level for quiet conditions but contamination from other sites was not consistently affected. During turbulent ventilation, activity had no apparent effect and Fig. 8 has not been complicated by the addition of points to illustrate this.

An operating-lamp over the table had no consistent effect on exposure to contamination though there was a slight but probably insignificant reduction of actual contamination under it for both turbulent and displacement systems.

\section{Comfort}

It has been suggested that air velocities associated with displacement ventilation may be too low for comfort. We find that in practice this is not so.

Comfort depends on temperature, humidity, and air movement, and unfavourable conditions in respect of any one of these can, within limits, be compensated by favourable conditions in respect of the others. For a ventilation system with both heating and cooling equipment, temperature and humidity can be therefore adjusted for comfort irrespective of air velocity, which can then be discounted in any comparison between turbulent and displacement ventilation. In British hospitals, however, it is not usual to include cooling equipment in ventilation systems which in hot weather, therefore, deliver air at ambient temperature. We have studied the performance of turbulent and displacement systems operating in this way.

In the experimental operating-room, two $2-\mathrm{kW}$. convector air-heaters and two $2-\mathrm{kW}$. radiators were arranged to represent sources of heat such as sterilizers, hot pipes, and operating-room staff. The room temperature became stabilized at $89^{\circ} \mathrm{F}$. $\left(22^{\circ}\right.$ above the outside temperature of $67^{\circ} \mathrm{F}$.) then the ventilation supplying 17 changes, hour was turned on. The turbulent system restabilized the temperature at $74^{\circ} \mathrm{F}$. and the displacement, apparently because of its property of replacing air rather than diluting it, gave stabilization at $69^{\circ} \mathrm{F}$.

No corresponding experiments were made to determine the abilities of these two systems to replace air humid from internal sources of steam, with drier air from outside but there seems no reason to suppose that this problem is fundamentally different from the mass replacement of bacterially contaminated or overheated air.

In a brief summertime survey of twelve operating-rooms with plenum ventilation (seven turbulent and five displacement) we found little relationship between calculated 'comfort values' and the opinions of surgeons and nurses. In general, however, there were more favourable comments for the displacement system. This was especially so in one hospital group where both types were available for comparison. The lower temperature and humidity from the displacement system was thought of more benefit than the greater air movement from the turbulent system. During cold weather, when the air for both systems had to be heated, both gave entirely comfortable conditions. 


\section{DISCUSSION}

The most surprising result of these investigations was the discovery that several recently-built plenum-ventilated theatres were not fully pressurized despite the fact that they were intended (and thought) to be so. Smoke testing to confirm that the installed plant performs in accordance with expectation is, apparently, not a routine practice. The input surplus needed to pressurize a room right down to floor level is much greater than has been provided in the past. It depends on door area and can be provided only on the assumption that not more than one door will be open at a time; and even for this it is so large that it can be reasonably attained only by dispensing with mechanical exhaust fans and using pressure-relief flapvalves instead. These have the additional advantage of providing a simple method of adjusting the pressure gradient, and thus the direction of air flow, between the various rooms of the suite.

The ease with which airborne cross-contamination occurs between twin operatingrooms with open communication stresses the need for doors in all openings. Indeed, apart from this, an open doorway from any pressure-ventilated room with highlevel inlets reduces both the bacteriological and the comfort value of the ventilation because air is lost through the upper part of the doorway before it reaches the lower regions where it is needed.

In welcome contrast to the difficulties of pressurizing a room and controlling direction of air flow was the finding that quite simple filtration methods ensured a flow of almost bacteria-free air. Our studies of filtration were made with a ventilation plant drawing air entirely from outside; but the mean size of contaminated particles is almost the same for hospital as for outdoor air so there is no bacteriological objection to recirculating part of the exhaust air when this is necessary for economy in extreme climates.

For removal of bacteria from sources inside the room, we have studied two fundamentally different methods of distributing the air-uniform mixing with turbulence, and downward displacement with a minimum of turbulence. After widespread contamination of the room, displacement was unquestionably better than turbulence; after localized contamination, turbulence was better if the contamination site was almost immediately over the table whilst displacement was better if the site was elsewhere. To use these findings as a basis for the choice of ventilation system we must know whether the main sources of airborne organisms during an operation are the relatively still surgeon and his assistants round the table or the more active nurses further away; and whether pathogenic bacteria are scattered from the human body and clothing above or below the table or are mainly disturbed from the floor by the staff as they move about their duties. Several workers have shown that dispersal of Staph. aureus, nowadays the most important wound pathogen, is closely associated with movement; that the perineum is an important dispersal site; and that the nasopharynx, rather surprisingly, is not the immediate source of many of the staphylococci in the air (Duguid \& Wallace, 1948; Hare \& Thomas, 1956; Shooter, Smith \& Hunter, 1959). Moreover, the actual dispersal sites should not be allowed overwhelming influence on the choice because 
they must inevitably vary a great deal, depending on which members of the staff happen to be carriers. The method giving the best clearance of the room as a whole may therefore be preferable. For these reasons we believe that the balance of evidence is in favour of displacement ventilation as recommended by Bourdillon \& Colebrook in 1946.

If a displacement system using the convenient ceiling diffusers is used there is little advantage in exceeding a ventilation rate of $1200 \mathrm{cu}$. ft./min. (17-20 changes/hr.) for the main room. This happens to be the same flow as that needed to ensure pressurization so we suggest that it is the rate that should be used.

On grounds of comfort there is little to choose between turbulent and displacement ventilation and none at all if full temperature-control, with heating and cooling, is available. Overheating of operating-rooms is common, but it is usually due to inadequate lagging and faulty siting of sterilizing equipment and hot pipes, to the common practice of leaving the sterilizing-room door open during operations, or to the absence of such a door. If these faults are avoided-and they are avoidable -efficient ventilation even without cooling can hold the temperature only two or three degrees above that outside; and since the maximum daytime temperature exceeds $78^{\circ} \mathrm{F}$. for an average of only 12 days a year in London and three in Glasgow there seems little justification for cooling equipment in Britain.

Ventilation systems of both types are of relatively simple design and can easily be installed in theatre suites. For turbulence three inlets along the top of one wall, with louvres to give a 45 degree downward slant to the airstream, and exhaust ports in any convenient position are sufficient. Downward displacement is best attained with a finely-perforated ceiling but the more convenient arrangement of six diffusers giving a horizontal spread of air is almost as good for any practicable ventilation rate; symmetrically placed low-level exhaust ports, one on each wall or two each on opposite walls are needed; a positive temperature-difference increases the displacement effect but a negative one does not abolish it. These conditions are rather more difficult to fulfil than those for turbulence but we have seen ingenious designs for doing so. The ceiling inlets call for space above the ceiling for air-ducts, or for ducts under the ceiling inside the room. Outside walls are not essential for the extra exhaust ports nor is complicated internal ducting because discharge through operating-room walls to an adjoining 'dirtier' room is acceptable; thus the operating-room exhaust ports may discharge into the corridor and anaesthetic, scrub and sink-rooms, but not into the sterilizing-room. A moderate positive temperature-difference can be attained for most of a typical British year if two precautions are observed: the ventilation plant should be the only source of heat when it is running so radiant panels, needed to maintain temperature when the ventilation plant is not in use, should be automatically turned off when the ventilation is switched on; and sources of 'wild heat' should be eliminated from the operatingroom for this reason as well as in the interests of comfort.

Finally, it should be remembered that whatever method is used for removing airborne bacteria, it must always be secondary to efforts at preventing their dis- 
semination (Blowers, 1958). We especially stress that though movement in the room may not seriously impede the removal of organisms that are already airborne, it is very much responsible for their actual presence.

\section{SUMMARY}

1. Pathogenic bacteria are removed from air by relatively simple filters having an efficiency of $99.9 \%$ for $5-\mu$ particles.

2. To prevent ingress of contaminated air from other parts of the hospital an operating-room should be pressurized by a flow of filtered air. An input flow of $1200 \mathrm{cu}$. ft. ( $34 \mathrm{cu} . \mathrm{m}$.) per min. will ensure this if mechanical exhaust fans are replaced by pressure-relief valves.

3. Other rooms of the suite should be ventilated in this way with flow rates depending on door area, and with pressure gradients adjusted by relief-valve loadings to cause air flow from dirtier to cleaner zones.

4. All openings between the rooms of an operating-suite should be fitted with doors to prevent airborne cross-contamination and high-level loss of ventilating air.

5. The relative merits of turbulent and downward-displacement ventilation have been studied and are discussed. The choice between them depends on the sites from which pathogenic bacteria are mainly disseminated during operations; these are not yet fully understood but the available evidence favours the displacement system. Methods for producing turbulent and displacement ventilation are described.

6. Discomfort from overheating of operating-rooms is largely due to faulty design and siting of sterilizing equipment. In Britain, if these faults are avoided, ventilation without cooling equipment can give comfortable conditions except on very rare occasions.

We wish to thank the Newcastle Regional Hospital Board for financing this investigation; the South Tees-side Hospital Management Committee for providing accommodation and other help; the War Office Microbiological Research Establishment and Dr J. R. May for advice and loan of equipment; Dr R. E. O. Williams and $\mathrm{Dr} \mathrm{O}$. M. Lidwell for general advice and many practical suggestions; Mr P. H. Knighton and Mr R. L. Wake for help in designing the experimental theatre; Carrier Engineering Company and Fairitt Engineering Company for help and loan of equipment; Dr T. Bedford and Professor C. P. Yaglou for valuable advice; Mrs R. Best, Miss W. Mahom, Mr W. H. Bound, Mr A. N. Hoskins Mr C. Allison and other members of the laboratory staff for much hard work; and the many surgeons and nurses who tolerated our investigations while they were working. 


\section{REFERENCES}

Blowers, R. (1958). In Medical Annual. Bristol: John Wright and Sons.

Blowers, R. Mason, G. A., Wallace, K. R. \& Walton, M. (1955). Lancet, ii, 786.

Bourdillon, R. B. \& Colebrook, L. (1946). Lancet i, 561 and 601.

Bourdillon, R. B., Lidwelx, O. M. \& Lovelock, J. E. (1948). Spec. Rep. Ser. med. Res. Coun. (Lond.), no. 262, p. 54.

Bourdillon, R. B., Lidwell, O. M. \& Thomas, J. C. (1948). Spec. Rep. Ser. med. Res. Coun. (Lond.), no. 262 , p. 19.

Duguid, J. P. \& Wallace, A. T. (1948). Lancet, ii, 845.

Hare, R. \& Thomas, C. G. A. (1956). Brit. med. J. ii, 840.

LIDWELL, O. M. (1959). J. sci. Instrum. 36, 3.

LOWBURY, E. J. L. (1954). Lancet, i, 292.

Lowbury, E. J. L. \& LILLy, H. A. (1955). J. Path. Bact. 70, 105.

LowbURY, E. J. L. \& LILLY, H. A. (1958). Brit. med. J., ii, 1334.

MAY, K. R. (1949). J. appl. Phys. 20, 932.

Shooter, R. A., Sмтth, M. A. \& Hunter, C. J. W. (1959). Brit. J. Surg. 47, 246.

Shooter, R. A., TAYlor, G. W., Eluis, G. \& Ross, J. P. (1956). Surg. Gynec. Obstet. 103, 257.

Williams, R. E. O. \& Lidwell, O. M. (1960). J. Hyg., Lond., 58, 449.

\section{EXPLANATION OF PLATES}

\section{Plate 1}

Ventilation by a turbulent system. Smoke introduced into the main supply duct mixes diffusely with the air in the room.

\section{Plate 2}

Ventilation by downward displacement. The absence of turbulence and removal of room air by bulk displacement are shown by the demarcation between the descending smoke and the clear area below it. The photograph also shows the spinning-top atomizer and the general construction of the experimental room. 


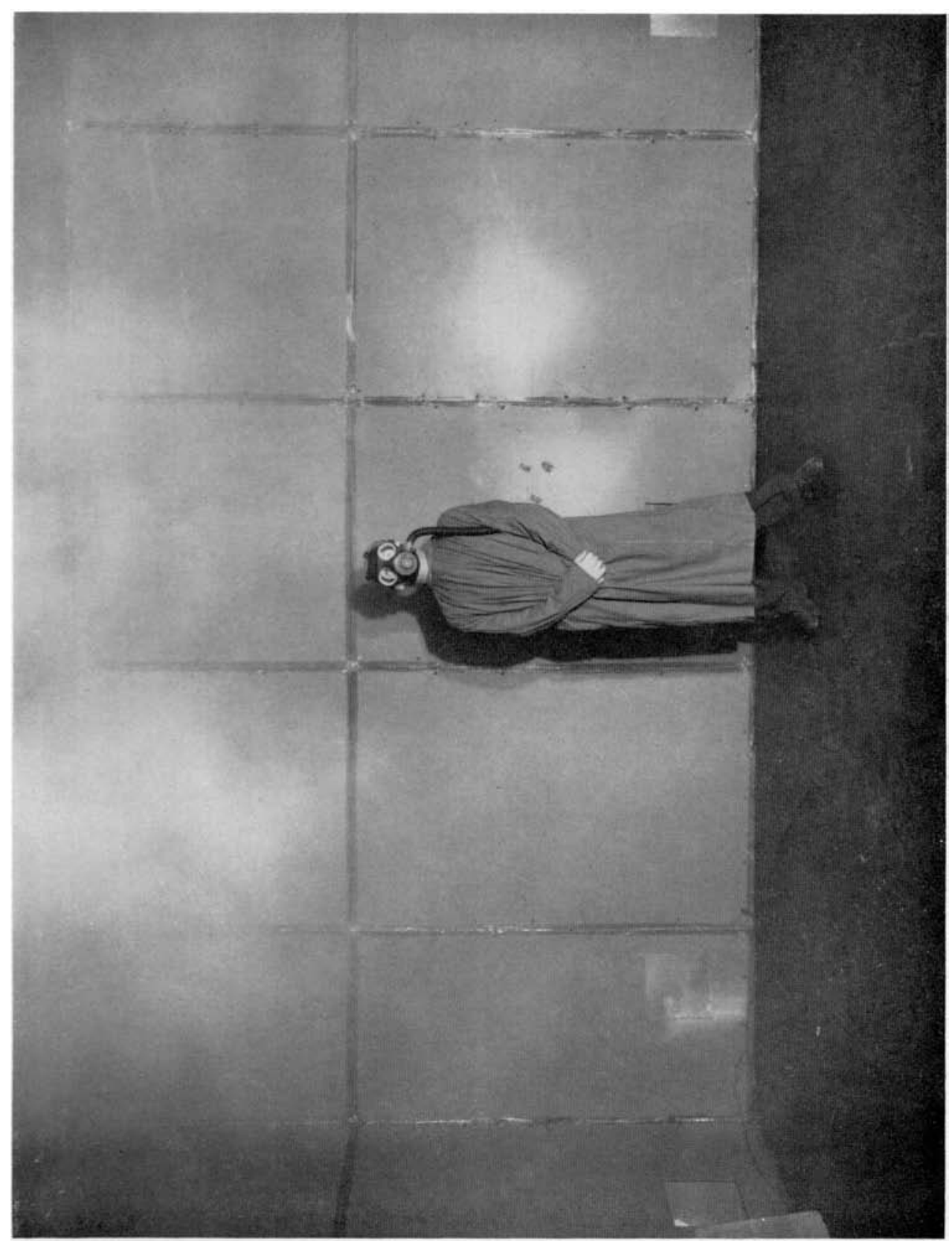




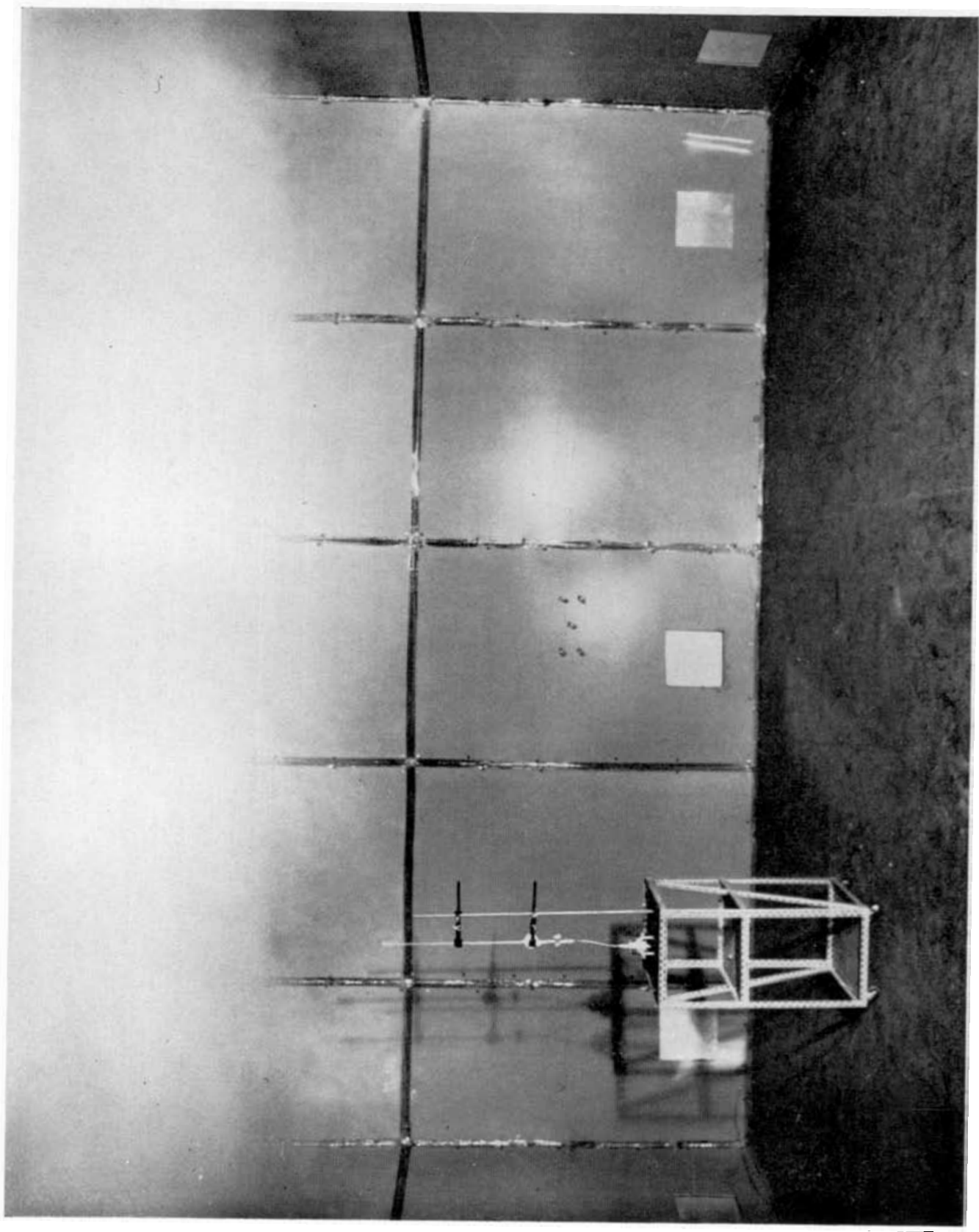

ROBERT BLOWERS AND BERYL CREW 